\title{
Suplementation Alfalfa (Medicago sativa L.) in commercial feed on physic and chemical quality meat of hybrid duck
}

\author{
Safira Amalina Addini, Bambang Suwignyo,", and Chusnul Hanim \\ Faculty of Animal Science, Universitas Gadjah Mada, Jl. Fauna No. 3, Bulaksumur, Yogyakarta, 55281, Indonesia
}

\begin{abstract}
The aimed of this study was to determine the effect of suplementation level of alfafa (Medicago sativa L.) on hybrid duck's meat quality with basal diet commercial feed. This study used in vivo tecnique on 108 hybrid ducks. The research consisted of 3 treatments and 6 replications, each replication consisted of 6 ducks. The treatments were $\mathrm{P} 1=$ commercial feed $+0 \%$ fresh alfafa, $\mathrm{P} 2=$ commercial feed $+5 \%$ alfafa, $\mathrm{P} 3=$ commercial feed $+10 \%$ fresh alfafa. Alfalfa was calculated in dry matter based but offered in the form as fed. Feed and water was offered ad libitum. The variables measured include product appereance, carcass quality, physic and chemical hybrid duck's meat. One way Completely randomized design was used in this research. All data collected was analized with Statistical Package for Sosial Science version 22. Data with significant differences were further tested with Duncan's new Multiple Range Test. Data resulted significant differences $(\mathrm{P}<0.05)$ on water content, $\mathrm{pH}$, water holding capasity, and coking loss of the meat among treatment, but not for crude protein, extract ether, and tenderness $(\mathrm{P}>0.05)$. Based on the data resulted, it can be concluded that commercial feed with $5 \%$ alalfa suplementation (P2) was the best treatment to the physic and chemical quality meat of hybrid duck.
\end{abstract}

Keywords: Hybrid duck, commercial feed, alfalfa, physic meat, chemical meat

\section{Introduction}

Duck meat is one of many animal protein that high on demand and easy to get by people. Duck meat consumtion level increase $13.19 \%$ from 2014 until 2018 [1]. People start to breed duck as an alternatives of animal's protein fulfillment beside chicken meat. The increasing need of duck meat demand insentive breeding, so quality feeding is indispensable for productivity and duck meat quality escalation.

One of the superiority of duck meat is that the meat is more savory compared to chicken meat, because of the accumulation of fat under the skin [2]. Duck meat has a weakness that is relatively high fat compared to other poultry [3]. Animals with high fat can cause a risk of disease for consumers. Improving the quality of duck carcasses can be done by reducing the fat of duck carcasses. One way to improve the quality of duck carcasses is the use of alfalfa supplementation in feed.

Alfalfa is known as a chlorofl producer which is used as a food supplement that can help improve metabolic function in the body. The content of alfalfa nutrients is crude protein of $17.2 \%$ to $24.1 \%$ [4]. Besides protein, alfalfa also contains high vitamins and minerals [5]. High crude fiber in alfalfa can reduce the rate of poultry's food disgestion [6]. High levels of saponin on alfafa which is $2 \%$ to $3 \%$ dry matter functioned as hypocholesterolemic, anti-cancer, anti-inflammatory and antioxidant [7]. Previous studies have shown that alfalfa feeding by $9 \%$ can increase the percentage of breast meat compared to the control group [8]. Nutrient of alfalfa in the second regrowth is CF $28.80 \%, 16$ hours $20.92 \%$ DM, 20 hours $89.38 \%$ OM and $9.16 \%$ EE [9]. Alfalfa also containing some essensial amino acid like lysine, leucine, methionine, and cysteine which usually found in soybean, corn and fish meal [10].

Based on this potential, alfalfa can be used as a food supplement to reduce cholesterol and improve the quality of duck meat. Therefore, in this study using alfalfa for duck feed supplementation expected to improve the physical and chemical quality of duck meat. Useful to provide information for the public and breeders on the use of alfalfa supplementation which can improve the appearance of production and carcass quality, physical and chemical hybrid duck meat.

\section{Materials and methods}

The poultries used for the study were MA hybrid ducks (Mojosari x Alabio) obtained from Kulon Progo. Maintenance began when the duck was DOD age until 40 days, ducks are grouped randomly in 18 cages, each cage has 6 ducks according to each treatment. The research materials used include fresh alfalfa, 108 DOD ducks and commercial BR-1 feed from Japfa. This research was experimentally using a Completely Randomized Design (CRD) in one directional pattern with 3 treatments and 6 replications, each replication consisting of 6 ducks. The treatments given were as follows: $\mathrm{P} 0=$ Commercial feed $+0 \%$ fresh alfalfa, $\mathrm{P} 1$ $=$ Commercial feed $+5 \%$ fresh alfalfa, $\mathrm{P} 2=$ Commercial feed $+10 \%$ fresh alfalfa.

\footnotetext{
* Corresponding author: bsuwignyo@ugm.ac.id
} 


\subsection{Feed consumption}

The feed offered and the rested were weighed and recorded to find out the amount of feed consumption. According Nuningtyas (2014) Feed consumption can be calculated by reducing the feed offered with the remaining feed as follows:

Feed consumption $=$ Feed offered - leftover feed (1)

\subsection{Physical meat}

pH. Meat $\mathrm{pH}$ is obtained after cutting and measuring using a $\mathrm{pH}$ meter. Water Holding Capacity. The water holding capacity is obtained from how much water is bound by the meat using the Hamm method, the formula is:

$$
\mathrm{Mg} \mathrm{H}_{2} \mathrm{O}=\frac{\text { wet area }}{0.0948}-8.0
$$

Cook Loss. The results of cooking loss is obtained from the reduced mass value of the meat after heating or cooking. Tenderness. Meat tenderness can be measured using the value of the Warner-Bratzler (WB) breakdown.

\subsection{Meat chemical}

Water content. Determinated by meat moisture using the method (AOAC, 1984). Extract Ether. Determinated by meat fat content using the Soxhlet extraction method. Crude Protein. Determinated by meat protein using the Kjedhal method.

\section{Data analysis}

Data from this study were analyzed using the Statistical Package for Social Science version 22 (SPSS Gmbh, Munich, Germany). Data with significant differences were further tested with Duncan's new Multiple Range Test (DMRT).

\section{Results and discussion}

\subsection{Chemical quality of hybrid duck meat}

The effect of alfalfa supplementation on commercial feed on the chemical quality of hybrid duck meat observed including water level, crude protein and crude fat shown in Table 1.

Tabel 1. Alfafa supplementation impact (0.5.10\%) in ration on hybrid duck meat chemical quality.

\begin{tabular}{lcccc}
\hline \multirow{2}{*}{ Parameter } & \multicolumn{3}{c}{ Alfalfa level(\%) } \\
\cline { 3 - 5 } & & 0 & 5 & 10 \\
\hline $\begin{array}{l}\text { Water } \\
(\%)\end{array}$ & Content & $75.85 \pm 2.40^{\mathrm{b}}$ & $75.83 \pm 1.87^{\mathrm{b}}$ & $81.02 \pm 0.21^{\mathrm{a}}$ \\
$\begin{array}{l}\text { Crude } \\
(\%)\end{array}$ & Protein & $22.47 \pm 1.11$ & $24.14 \pm 2.04$ & $21.93 \pm 2.02$ \\
Extract Ether (\%) & $2.94 \pm 0.80$ & $2.94 \pm 0.85$ & $3.56 \pm 2.12$ \\
\hline
\end{tabular}

Note: $^{\mathrm{a}}{ }^{\mathrm{b}}$ numbers with different superscripts show significantly different $(\mathrm{P}<0.05)$

\subsubsection{Water content}

Table 1 shows that alfalfa supplementation in commercial feed significantly affected the water content of hybrid duck meat $(\mathrm{P}<0.05)$. The highest water content is at the alfalfa supplementation by $10 \%$, while the lowest water content is at the level of alfalfa supplementation at $5 \%$. Water level is the biggest chemical composition compared to protein and fat from meat. Water is a major component of all animal body tissues and an extracellular constituent. Water also a universal medium [11].

Broiler chicken water level is to $65 \%$ to $80 \%$ [12]. Duck meat water content already high at the time of cutting. It is because the water content in the study influenced by the water content in the two basic ingredients namely duck meat and alfalfa. Meat that stored for a long time will cause water content increasement. Water level increasement caused by microbial activity in meat. This is in in line with [13] opinion, meat that is stored too long will cause the release of water bound to be free water. Thus, the longer the meat is stored will cause an increase in the water level [14].

\subsubsection{Crude protein}

The results showed the crude protein level of hybrid duck meat in each treatment given alfalfa supplementation of $0 \%, 5 \%$ and $10 \%$ respectively $22.47 \%, 24.14 \%$ and $21.93 \%$. The highest crude protein was at the level of alfalfa $5 \%$ supplementation at $24.14 \%$, while the lowest protein content was at the level of alfalfa $10 \%$ supplementation at $21.93 \%$. The results of the analysis showed no significant difference $(\mathrm{P}>0.05)$ on the crude protein of hybrid duck meat. Crude protein of the meat is closely related to the storage process. High protein consumption will affect the intake of protein in meat and sufficient amino acids in the body so that the body cells metabolism takes place normally. Whereas treatment with low protein content will have a low meat protein content as well [15]. Based on the measured amino acid content, these results indicate that alfalfa can be a suitable alternative for other feed materials that provide necessary amounts of several amino acids for poultry including corn meal (lysine and tryptophan), soybean meal (methionine, cysteine, lysine and tryptophan) and fish meal (methionine and lysine) [10].

Antioxidants derived from plants are very good in enhancing meat quality because it can inhibit or prevent damage due to the free radicals impact [16]. Alfafa contains saponins, flavonoids as anti-inflammatory, antibodies, antiparasites and antioxidants. Kecombrang extract has a high concentration of antioxidants, and has a strength large enough to prevent free radical compounds so as oxidation prevention [17].

The use of antimicrobial active compounds must be used with high concentrations so that they are toxic to microbes by damaging cell walls and impacting inhibitation of microbial growth [18]. The greater the antimicrobial inhibition caused by active antimicrobial 
ingredients, so the chemical damage to broiler chicken meat by microbes will be reduced.

\subsubsection{Extract ether}

The hybrid duck extract ether with the effect of alfalfa supplementation on commercial feed had no significant difference in each treatment $(\mathrm{P}>0.05)$. The highest average fat content occurs in the treatment with $5 \%$ alfalfa supplementation. Along with increasing alfalfa supplementation, meat fat levels increase.

Extract ether of broiler chicken breasts ranges from $1.81 \%$ to $2.31 \%$ [19]. The use of active substances such as saponins, vitamin C, flavonoids and tannins also reduce fat accumulation [20]. Alfallfa contains saponins, flavonoids as anti-inflammatory, antibodies, antiparasites and antioxidants. The addition of $5 \%$ alfalfa supplementation is the best treatment compared to the addition of $10 \%$ alfalfa supplementation. High extract ether can be caused by the use of an incorrect number of samples, the length of time of extraction and the improper cooling time. Another possibility is the presence of several substances that are extracted as fat so that the fat level is much greater.

\subsection{Physical quality of hybrid duck meat}

The results of physical quality examinatin $(\mathrm{pH}$, Water Holding Capacity (WHC), cooking loss, tenderness) of hybrid duck meat to alfalfa supplementation in commercial feed is presented in Table 2 .

Table 2. Effects of alfalfa supplementation (0.5.10\%) rations on physical quality hybrid duck meat

\begin{tabular}{|c|c|c|c|}
\hline \multirow{2}{*}{ Parameter } & \multicolumn{3}{|c|}{ Alfalfa level(\%) } \\
\hline & 0 & 5 & 10 \\
\hline $\mathrm{pH}$ & $6.87 \pm 0.04^{\mathrm{ab}}$ & $6.90 \pm 0.08^{b}$ & $6.79 \pm 0.11^{\mathrm{a}}$ \\
\hline WHC (\%) & $53.50 \pm 10.54^{\mathrm{a}}$ & $42.62 \pm 3.69^{a}$ & $46.62 \pm 9.16^{\mathrm{b}}$ \\
\hline Cooking & $25.86 \pm 2.53^{\mathrm{a}}$ & $30.64 \pm 1.94^{b}$ & $28.46 \pm 3.74^{\mathrm{ab}}$ \\
\hline $\operatorname{Loss}(\%)$ & $2.34 \pm 0.59$ & $2.40 \pm 0.43$ & $2.23 \pm 0.42$ \\
\hline Tenderness $(\%)$ & & & \\
\hline
\end{tabular}

\section{$4.3 \mathrm{pH}$}

The analysis showed the use of alfalfa supplementation in commercial feed significantly affected $(\mathrm{P}<0.05)$ the hybrid duck meat $\mathrm{pH}$. The results showed that the highest $\mathrm{pH}$ value at $5 \%$ alfalfa supplementation level was 6.90 and the lowest $\mathrm{pH}$ value at $10 \%$ alfalfa supplementation level was 6.79 .

The use of feed which has a high carbohydrate content can affect broiler chicken muscle glycogen levels so that it can affect the meat $\mathrm{pH}$ [21]. Alfalfa's crude fiber is one of the feeds that affects the $\mathrm{pH}$ value. Higher alfalfa supplementation can reduce the meat's $\mathrm{pH}$. That feed supplemented with purslane flour by the highest administration $(6 \%)$ can reduce the $\mathrm{pH}$ value [22]. The control feed had a $\mathrm{pH}$ value of $5.91 \%$ while the $6 \%$ supplementation feed was $5.77 \%$.

\subsection{Water holding capacity}

Alfalfa supplementation of hybrid duck meat water holding capacity on commercial feed has a different value in each treatment. The highest average value of water holding capacity shown in the treatment with alfalfa supplementation of $0 \%$. Along with increasing alfalfa supplementation, the binding capacity of the meat water decreases.

The average value of water holding capacity by alfalfa supplementation of $0 \%, 5 \%$ and $10 \%$ in commercial feed has a significant effect $(\mathrm{P}<0.05)$ on hybrid duck meat. The most water holding capacity of hybrid duck meat is in the treatment of $0 \%$ alfalfa supplementation, because more more reactive groups can increase water molecules. The high water holding capacity can also be caused by the high and low $\mathrm{pH}$ of the meat produced. A decrease in $\mathrm{pH}$ causes denaturation of proteins [23]. As a result of protein denaturation, there is a decrease in protein solubility which causes the water holding capacity to decrease.

The ability of meat to hold water is an important trait. High water holding capacity, so the meat has good quality. The water holding capacity in this study is within the normal range. The water holding capacity of meat is around $20 \%$ to $60 \%$ [24]. In connection with the explanation above, it can be concluded that the decreasing water content of hybrid duck meat.

\subsection{Cooking loss}

The highest average value of cooking loss occurred at $5 \%$ alfalfa supplementation in commercial feed by $30.64 \%$. The analysis showed that the use of alfalfa supplementation in commercial feed significantly affected $(\mathrm{P}<0.05)$ the $\mathrm{pH}$ of hybrid duck meat. The amount of cooking loss is influenced by the $\mathrm{pH}$ value and the holding capacity of meat water. The higher the temperature and cooking time, the higher cooking loss values in broiler chickens [25].

This is consistent with the results of the study, the highest value of cooking loss in alfalfa supplementation of $5 \%$ in commercial feed was $30.64 \%$ with a water holding capacity of $42.62 \%$. The results obtained are classified in the normal range. The value of meat cooking loss is generally between $1.5 \%$ to $54.5 \%$ with a range of $15 \%$ to $40 \%$ [26].

This is in accordance with the study done which are factors that affect cooking loss including $\mathrm{pH}$ value, length of muscle fiber sarcomeres, pieces length of muscle fibers, myofibril contraction status, sample size and weight, meat cross section, heating, variety related to meat fat, age, and energy consumption in feed [27]. The value of cooking loss is closely related to the water holding capacity [28]. The higher water holding capacity will result in lower cooking loss in meat. This is consistent with the results of the study, the highest value of cooking loss in alfalfa supplementation of $5 \%$ in commercial feed was $30.64 \%$ with a water holding capacity of $42.62 \%$.

The amount of cooked meat loss is influenced by the $\mathrm{pH}$ of the meat. The $\mathrm{pH}$ value affects cooking loss [26]. The value of cooking loss in the study has the highest of 
giving $5 \%$ alfalfa supplementation in commercial feed of $30.64 \%$ with a pH of 6.90 while the lowest cooking loss comes from giving alfalfa supplementation of $0 \%$ with a $\mathrm{pH}$ of 6.87 .

\subsection{Tenderness}

The tenderness level of hybrid duck meat with alfalfa supplementation of $0 \%, 5 \%$ and $10 \%$ in commercial feed showed no difference. The results of the analysis did not significantly effect $(\mathrm{P}>0.05)$ on the hybrid duck meat's tendency. Increased tenderness occurs in the administration of alfalfa $5 \%$ by $2.40 \%$. Tenderness is closely related to the process of boiling meat.

Supplementation of $10 \%$ alfalfa in commercial feed had no effect on meat tenderness because there was no change in the structure of the auto protein. Boiling the meat causes damage and changes in the structure of muscle protein, especially in actin and myosin. The process of boiling meat is one way to softening meat with cooking, it can causes protein denaturation. Protein denaturation is the breakdown of proteins into smaller units [29]. One of the factors that affect meat tenderness is the postmortem factor, one of which is the cooking method by boiling [24].

\section{Conclusion}

Based on the results of the research, it can be concluded that the best treatment of alfalfa supplementation feed to determine the meat physical and chemical best quality that is the treatment with $5 \%$ alfalfa supplementation on commercial feed. for the future maintenance should be carried out in a longer period of time.

The authors are grateful to the Faculty of Animal Sciences, Gadjah Mada University, for funding this research in the "Program Hibah Pascasarjana". The Authors contribution are as follow: Safira Amalina Addini, Bambang Suwignyo and Chusnul Hanim.

\section{References}

1. Dirjen PKH, Direktorat Jendral Peternakan dan Kesehatan Hewan, Jakarta (2019)

2. A.P. Damayanti, Jurnal Agroland, 13,3:3133-3117 (2006). [in Bahasa Indonesia]

3. N. Huda, A.A. Putra, R. Ahmad, Current Research in Poultry Science, 1:1-11 (2011)

4. J. Sirait, M. Syawal, K. Simanihuruk, Tanaman alfalfa adaptif tanaman dataran tinggi beriklim basah sebagai sumber pakan: Morfologi, produksi dan palatabilitas. In: Pros. Seminar Nasional Teknologi Peternakan dan Veteriner. Bogor, 3 - 4 Agustus 2010. Puslitbang Peternakan, Bogor. pp. 519-528 (2010). [in Bahasa Indonesia]

5. Sajimin, N.D. Purwantari. Tanaman Alfalfa sebagai komoditas harapan pakan ternak: Pengaruh serangan hama terhadap produktivitas hijauan pada pemotongan pertama. In: Seminar Nasional Perhimpunan Entomologi Indonesia, 16-17
February 2011. Universitas Padjadjaran, Bandung. 11 (2011). [in Bahasa Indonesia]

6. I.R. Sibbald, Poult. Sci. 58:446-459 (1979).

7. P.T. Klita, G.W. Mathison, T.W. Fenton, R.T. Hardin, J. Anim. Sci. 74:1144-1156 (1996).

8. J.F. Jiang, X.M. Song, X. Huang, J.L. Wu, W.D. Zhou, H.C. Zheng, Y.Q. Jiang. British Poultry Science, 53,5:681-688 (2012).

9. B. Suwignyo, F. Izzati, A. Astuti, E.A. Rini, IOP Conf. Series: Earth \& Envr. Sci. 465: 1-6 (2020).

10. B. Suwignyo, A. Mustika, Kustantinah, L. M. Yusiati, B. Suhartanto. American Journal of Animal and Veterinary Sciences. 15,2:118-122 (2020).

11. M.D. Judge, E.D. Aberle, J.C. Forrest, H.B. Hendrick, R.A. Merkel. Principles of Meat Science. 2nd ed. Kendall/Hunt Publishing Co., Dubuque, Iowa (1989).

12. J.C. Forrest, E.D. Aberle, H.B. Hedrick, M.D. Judge, R.A. Markell. Principle of Meat Science. W. H. Freman and Co. San Fransisco (1975).

13. A.A. Ressang, S. Karmas. Ilmu Kesehatan Daging. Edisi kedus. Fakultas Kedokteran Hewan, Institut Pertanian Bogor. Bogor (1989). [in Bahasa Indonesia]

14. H. Kasmadiharja, Kajian Penyimpanan Sosis, Nuget Aya, dan Daging Ayam Berbumbu dalam Kemasa Polipropilen Rigid. Undergraduate Thes. Fakultas Teknologi Pertanian. Isntitut Pertanian Bogor. Bogor (2008). [in Bahasa Indonesia]

15. L.R. Kartikasari, Soeparno, Setiyono. Buletin Peternakan 25,1:33-39 (2001). [in Bahasa Indonesia]

16. V. Velasco, P. Williams. Chilean Journal Of Agricultural Research, 71,2:313-322 (2011).

17. A. Krismawati, Pengaruh Ekstrak Tanaman Ceremai, Delima Putih, Jati Belanda, Kecombrang dan Kemuning secara In Vitro terhadap Proliferasi Sel Limfosit Manusia. Undergraduate Thesis. IPB (2007). Bogor. [in Bahasa Indonesia]

18. A. Komariah, Jurnal Industri Pangan, 2, 1 (2004). [in Bahasa Indonesia]

19. T. Hudaya, S. Prasetyo, A.P. Kristijarti, Jurnal Industri Pangan, 2 (2013) [in Bahasa Indonesia]

20. Y. Fenita, O. Mega, E. Daniati, Jurnal Sain Peternakan Indonesia, 4,1 (2009) [in Bahasa Indonesia]

21. A.H. Prayitno, E. Suryanto, Zuprizal. Buletin Peternakan, 34,1:55-63(2010). [in Bahasa Indonesia]

22. L.R. Kartikasari, S.H. Bayu, S. Iwan, M.P.N. Adi, Jurnal Teknologi Pangan, 12,2:64-71(2018). [in Bahasa Indonesia] 